\title{
Pan-americanismo e política externa do Brasil no final do Império e começo da República: uma leitura a partir de Salvador de Mendonça
}

\author{
Américo Alves de Lyra Júnior ${ }^{1}$
}

\begin{abstract}
Resumo
O presente artigo apresenta as ideias de pan-americanismo da geração que ocupava cargo de relevância no período final do Império e começo da República brasileira. Salvador de Mendonça foi ministro plenipotenciário nos Estados Unidos e acompanhou todo desenvolvimento da mudança de regime na Primeira Conferência Pan-americana, nos Estados Unidos, tendo sido ativo na defesa da República nascente.
\end{abstract}

Palavras-chave: Pan-americanismo, Salvador de Mendonça, Política Externa do Brasil

\begin{abstract}
The present article presents the ideas of Pan-Americanism of the generation that has held relevant position in the final period of the Empire and the beginning of the Republic in Brazil. Salvador de Mendonça was Plenipotentiary Minister in the United States and has followed every development and regime change in the first Pan-American Conference in the United States, having been active in the defense of the nascent Republic.
\end{abstract}

Keywords: Pan Americanism, Salvador de Mendonça, Brazil's Foreign Policy

Artigo recebido em: 06/06/2013

Artigo aprovado em: 25/09/2013

\section{Introdução}

$\mathrm{O}$ artigo discute as percepções de Salvador de Mendonça sobre o pan-americanismo e a política externa do Brasil do final do Império ao começo da República. Mendonça ocupou a função de Ministro Plenipotenciário nos Estados Unidos da América e foi delegado da Primeira Conferência Internacional Americana ${ }^{2}$, mais conhecida como Primeira Conferência Pan-americana.

Como delegado brasileiro nessa Conferência, Salvador de Mendonça acompanhou a troca de

\footnotetext{
${ }^{1}$ Professor de História da América e História das Relações Internacionais, Universidade Federal de Roraima (UFRR), Brasil. E-mail: americodelyra@uol.com.br

${ }^{2}$ De outubro de 1889 a abril de 1890.

Revista Eletrônica da ANPHLAC, ISSN 1679-1061, n.15, p. 132-154, jul./dez. 2013. 
regimes no Brasil e se empenhou pelo reconhecimento norte-americano da novel República. No encontro, Mendonça destacou-se ao apresentar Projeto de Arbitramento Obrigatório, o qual foi pensado com o secretário norte-americano James Blaine. O projeto Blaine-Mendonça foi aprovado, com algumas modificações, em 18 de abril de 1890. Ressalta-se que o brasileiro teve contribuição dos argentinos Roque Sáenz Peña ${ }^{3}$ e Manuel Quintana ${ }^{4}$ na redação da proposta em voga.

O projeto foi reprovado pelo congresso estadunidense, obedecendo a interesses políticos do então presidente republicano Benjamin Harrison. Harrison sentia-se ameaçado pelo também republicano James Blaine, que poderia se beneficiar eleitoralmente com o Projeto de Arbitramento Obrigatório. A censura norte-americana influenciou a reprovação do projeto nos parlamentos de outras nações americanas. A despeito da onda de condenação, observa-se, nesse tópico, a diferença de orientação da política externa do Brasil, promovida por Rio Branco, quanto ao panamericanismo, num momento em que o Brasil buscava ampliar suas relações com o continente americano para além dos Estados Unidos. Outra diferença se dá em relação à imagem de Salvador de Mendonça. A mais conhecida mostra Mendonça como um comprador ingênuo de obras de artes falsas e agente dos interesses norte-americanos.

Salvador de Mendonça teve longa experiência diplomática nos Estados Unidos, sendo ministro plenipotenciário da década de 1870 aos primeiros anos de 1900. Além disso, Mendonça associou suas experiências de jornalista e militante da causa republicana em tempos idos, associação que lhe permitiu ter reflexões de fundo sobre um período pouco estudado em termos de relações internacionais do Brasil: o da transição do Império para a República.

Para trabalhar o período em tela, o artigo se divide em três eixos autônomos e complementares. O primeiro apresenta um período de inovações sobre a política externa do Brasil, caracterizando as relações do país, em um cenário internacional de mudanças. Em meio a essas mudanças, o país buscava uma condição de potência periférica regional. Posteriormente, discute-se a noção de aristocracia nacional para Salvador de Mendonça, compreendida em um contexto de mudanças de conteúdo da Doutrina $M_{0} \operatorname{los}^{5}$ e de expansão estadunidense. Como último eixo, temos reflexões sobre a participação brasileira na Primeira Conferência Internacional Americana e do Projeto de Arbitramento Obrigatório.

\footnotetext{
${ }^{3}$ Foi presidente da Argentina de 1910 e 1914.

${ }^{4}$ Presidente argentino de 1904 a 1906.

${ }^{5}$ Compreende-se que a Doutrina de Monroe é um nome vago e com larga extensão de sentidos, posto não ser de fato uma doutrina. Entende-se que seria preferível usar o termo monroísmo para expressar, com maior exatidão, essa política dos Estados Unidos. Mas optou-se, talvez por um excesso de zelo, por conservar a linguagem de Salvador de Mendonça.
}

Revista Eletrônica da ANPHLAC, ISSN 1679-1061, n.15, p. 132-154, jul./dez. 2013. 


\section{Décadas de mudanças na política externa do Brasil: distensão, universalismo e aproximação em relação aos Estados Unidos}

Nesta seção, discutem-se os temas distensão, universalismo e aproximação em relação aos Estados Unidos, na perspectiva de uma política externa sob novo formato, porque perseguia novos objetivos, os quais serão apreciados ao longo do texto.

A política externa do Brasil sofreu mudanças no período compreendido entre as décadas de 1870 e 1880 . Na primeira década, situa-se o término da guerra no sul ${ }^{6}$, que permitiu, de acordo com Clodoaldo Bueno Amado Cervo (2001), a ascensão e queda da política do Império brasileiro. Pretendeu-se tornar o país uma potência periférica regional, que seria autoformulada, contínua e racional, porque guiada por objetivos próprios. Antes da derrocada do Império, no ano de 1889, essas mudanças de fundamentos da política externa se manifestaram por tendências de distensão e universalismo até a emergência da República.

A distensão deu-se por três razões de Estado: os bons resultados na guerra no sul, o fim dos atritos com a Inglaterra por conta de questões fronteiriças, sem o recurso da guerra, posto que a diplomacia procurou pender a balança de poder para o Brasil. Para lograr o intento, tentou-se atrair alguns países hispano-americanos para a esfera de influência brasileira, como a Bolívia e o Chile. Ao primeiro, prometeu-se uma saída para a Bacia Amazônica e o uso da estrada Madeira-Mamoré, a ser construída, por meio de um tratado de amizade, assinado em 1867. Com o Chile, deu-se a troca de representantes diplomáticos de alto nível. No caso da Inglaterra, como lembra Leslie Bethell (2001, p.589), suas relações com a América Latina eram comercialmente favoráveis, de modo que os seus interesses políticos estavam contemplados no continente americano.

O universalismo, por seu turno, baseou-se na busca de extensão e de prestígio para a ação externa do Império. Para isso, o imperador visitava diversas regiões do mundo, e o país participava de feiras, foros de arbitramento e congressos internacionais. Procuravam-se, também, contatos com o Oriente, e o Brasil envolvia-se com o pan-americanismo em companhia dos Estados Unidos, mantendo reservas. A diplomacia imperial temia um sistema interamericano por entender que, nele, os estadunidenses imporiam sua força e conquistariam liderança. Além do que, a simpatia dessa diplomacia estava, ainda, voltada para a Europa.

No tocante à aproximação do Brasil com os Estados Unidos, Salvador de Mendonça (1913,

\footnotetext{
${ }^{6} \mathrm{O}$ citado confronto representou um conjunto de disputas com os países da Bacia do Prata que, segundo Clodoaldo Bueno e Amado Cervo (2001, p.109), passaram por sete fases assim distribuídas: cooperação para defesa das independências (1822-24); guerra da Cisplatina (1825-28); política de neutralidade (1828-43); intervenção (1844-52); presença brasileira ativa (1851-64); novamente a intervenção (1864-76) e o retraimento vigilante (1877-89).
}

Revista Eletrônica da ANPHLAC, ISSN 1679-1061, n.15, p. 132-154, jul./dez. 2013. 
p. 82) comentou sua conversa com o presidente norte-americano Grover Cleveland ${ }^{7}$ e posterior comunicação da mesma a Pedro II, no ano de 1887. O presidente desejava um tratado comercial com o Império, por entender que "os bons negócios fazem os bons amigos" (p. 82). Os interesses estadunidenses nas demais nações americanas eram, a esse tempo, de caráter comercial, o que se manifestaria na Primeira Conferência Internacional Americana.

Cleveland afirmava ser do seu intento a amizade das nações do continente americano, como previsto pela Doutrina de Monroe. Informava que Mc Greary havia apresentado projeto de lei ${ }^{8}$ que permitia ao presidente convidar as nações americanas para uma conferência, na qual seriam estudadas a expansão dos mercados e o melhoramento das relações comerciais sob a égide da paz. A Conferência Internacional Americana ocorria em um período de crescimento comercial e industrial para a economia estadunidense, colocando, a partir da segunda metade do século XIX, os fatores econômicos e financeiros em posição privilegiada no relacionamento entre os Estados Unidos e os demais países. James Blaine, secretário de Estado norte-americano, convocaria as nações do hemisfério, excetuando-se o Canadá, para a Conferência Internacional Americana nesse contexto (BUENO, 1997, p.4).

Pedro II, que estava na Europa, gostou do que ouviu e orientou Salvador de Mendonça (1913, p.85) a retornar ao Brasil para convencer o governo sobre a urgência do pretendido tratado comercial. Mendonça chegou ao Rio de Janeiro no mês de dezembro de 1887, para conversar com o governo, que era conservador. Ele encontrou resistências àquele tratado comercial por parte de Francisco Belisário, ministro da fazenda, que entendia a aproximação com os Estados Unidos como prejudicial ao Império. Com a mudança de gabinete, Salvador de Mendonça considerou ter melhores chances de obter algum êxito para o tratado, mas o novo gabinete, com o conselheiro João Alfredo, continuou conservador, e as resistências permaneciam. Nesse gabinete, Mendonça encontrou a indisposição do ministro de estrangeiros, Rodrigo Silva, bem como dos ministros da agricultura e do Império, Antonio Prado e Costa Pereira, respectivamente. Outra ocasião em que o desejo de aproximação com os Estados Unidos se manifestou deu-se quando Pedro II chamou Mendonça a Petrópolis. O imperador expôs a intenção de convidar o presidente dos Estados Unidos para árbitro na questão das Missões.

Essa política de distensão e universalismo procurava, ao mesmo tempo, inserir o Brasil em um cenário internacional e dar respostas a uma vida doméstica conturbada, com problemas relativos

\footnotetext{
${ }^{7}$ Presidente em dois mandatos não consecutivos. O primeiro mandato foi de 1885 a 1889 , e o segundo mandato de 1893 a 1897.

${ }^{8}$ O projeto de lei foi apresentado a 29 de março de 1886.
}

Revista Eletrônica da ANPHLAC, ISSN 1679-1061, n.15, p. 132-154, jul./dez. 2013. 
à abolição da escravatura, à propaganda republicana e à necessidade de mão de obra. Problemas que, para Boris Fausto e Fernando J. Devoto (2004, p.59), dizem respeito ao ocaso de uma classe dirigente e ao término de um sistema político, os quais não teriam deixado muitos nostálgicos no Brasil, posto a República ter absorvido, com relativa celeridade, parcela significativa dos homens públicos do regime decaído.

No caso da inserção internacional do Brasil, as relações internacionais baseavam-se na expansão colonial europeia, no crescimento da concorrência internacional, em uma nova onda de progresso, na queda dos preços agrícolas, no retorno do protecionismo e nas suas consequentes disputas de tarifas e rivalidades, quando fracassavam os concertos em torno dos tratados de comércio (BUENO e CERVO, 2001, p.130). Dessa forma, enfocam-se os ambientes políticos externos e internos que envolviam a atenção brasileira.

Quanto ao cenário internacional, três países se destacavam. A Alemanha bismarckiana, os Estados Unidos e o Japão adquiriram proeminência, porque desejavam ampliar seu papel nesse cenário. Eles adotaram posturas imperialistas nas relações estabelecidas entre as nações. A Alemanha, por exemplo, administrava as relações intereuropeias, e os Estados Unidos ambicionavam o controle da América Latina por meio do comércio, no momento em que a Inglaterra perdia o controle do equilíbrio do poder europeu. Tendo esse cenário por pano de fundo, a proposta do presidente norte-americano Grover Cleveland a Salvador de Mendonça (1913) é bastante sugestiva. A Cleveland interessavam as relações bilaterais Brasil/Estados Unidos econômica e politicamente. Mendonça as percebia como interessantes do ponto de vista econômico, porque favoreceria ao seu governo o escoamento da produção agrícola, bem como:

(...) podiamos ainda garantir a isencao de direitos, ja existente para os nossos principaes productos de exportacao, o cafe e a borracha, e alcancar isencao egual para o nosso assucar e alguns favores para outros productos nossos, carecedores de mercado, em troca de algumas concessoes de nossa parte.

A penuria e que se achavam os Estados do Norte, - excepção feita do Para [sic] e do Amazonas, - em razão do baixo preço que obtinha a sua producção, levou os tres estadistas ${ }^{9}$ citados a acceitarem o meu alvitre, e ao deante veremos que se não enganaram. (MENDONÇA, 1913, p. 96)

Para os Estados Unidos, o mercado brasileiro representava uma oportunidade de enfrentar a concorrência e o domínio britânicos na América Latina. Os estadunidenses, no último quartel do século XIX, redescobriram essa porção da América e formularam uma política externa panamericana com claros objetivos econômicos. Da década de 1850 à década de 1870, comerciantes e

\footnotetext{
${ }^{9}$ Os três estadistas citados são os conselheiros João Alfredo, Jose Antonio Saraiva e Thomaz Coelho.
}

Revista Eletrônica da ANPHLAC, ISSN 1679-1061, n.15, p. 132-154, jul./dez. 2013. 
industriais norte-americanos preferiram não concorrer com os ingleses e contribuíram para que seu governo privilegiasse tratados bilaterais com países latino-americanos. Com a mudança de planos, o mercado brasileiro tornou-se interessante por ser o mais próspero da América do Sul, bem como, ao Brasil, pendia uma balança de poder favorável no continente sul-americano.

Como lembra Clodoaldo Bueno e Amado Cervo (2001, p. 131), a saída brasileira do Prata prejudicou a estabilidade institucional e financeira da Argentina. No tocante ao Chile, o não pagamento da dívida afetou apenas o barão de Mauá que auxiliou financeiramente à Monarquia brasileira a pedido do visconde do Uruguai. A ajuda do barão se deu em virtude de a França ter retirado recursos financeiros do Chile, no momento em que o visconde procurava resolver a questão do Prata através do acesso fluvial a Mato Grosso. Por meio desse acesso fluvial, ele procurava estabelecer a política brasileira contra o governo de Juan Manuel de Rosas, de Buenos Aires, e o de Manuel Oribe, do Uruguai. O visconde do Uruguai adotava essa postura agressiva para atender à solicitação de Andrés Lamas, ministro do Uruguai no Rio de Janeiro. Mas, com o término da questão, o governo do Brasil não cobrou as dívidas do Chile e abandonou Mauá à própria sorte. Para Bueno e Cervo (2001), a atitude do governo contribuiu com interesses ingleses de falência internacional do barão de Mauá e do retorno das aplicações e regras de cobrança britânicas.

Outra vantagem dessas relações bilaterais, para o Brasil, se dava com seu projeto de modernização conservador, porque não previa indústrias de transformação de matérias-primas. Depois, o país acumulara excedentes por conta dos superávits da balança comercial, que contribuíram para amortizar empréstimos e custear as exportações, importações, transportes e seguros. Grover Cleveland solicitava esses recursos brasileiros para fazer negócios com os Estados Unidos, uma vez que havia um desequilíbrio comercial entre as duas nações americanas.

Salvador de Mendonça (1913, p. 82) conversou com o presidente estadunidense que, na ocasião, comparou dados estatísticos sobre o comércio dos dois países. O Brasil só importava o equivalente a uma oitava parte do volume de produtos brasileiros que entravam nos Estados Unidos. As exportações norte-americanas eram taxadas na sua totalidade, enquanto as brasileiras alcançavam o índice de 6\%. Grover Cleveland criticava esse desequilíbrio comercial que, segundo ele, prejudicava as duas maiores nações americanas.

Salvador de Mendonça (1913, p. 84) contra-argumentava, no sentido de defender as rendas aduaneiras do Brasil. Mendonça noticiava que os Estados Unidos eram-nos superiores industrialmente e que poderiam fornecer tudo quanto os brasileiros importavam da Europa, de modo a comprometer aquelas rendas aduaneiras, tidas como indispensáveis à despesa nacional. $\mathrm{O}$ presidente Grover Cleveland insistia no equívoco do brasileiro quanto às rendas aduaneiras, porém,

Revista Eletrônica da ANPHLAC, ISSN 1679-1061, n.15, p. 132-154, jul./dez. 2013. 
apresentou uma proposta, como se observa na passagem a seguir:

[...] os Estados Unidos na [sic] nos podiam fornecer 45\% dessa importação que isso nos deixaria ainda renda avultada. Fazendo eu ali a conta approximada do que renderiam esses 45\% da nossa importação, pude provar-lhe a insufficiencia dessa receita para as nossas despesas administrativas. Offereceu-me entao um alvitre radical: constituirem os Estados Unidos e o Brazil um zolverein com a troca de produtos livre de todos os direitos e impostos, sommarem as suas receitos [sic] aduaneiras e dividirem-'as depois por capitacao. E logo mostrou-me que, em tal hypothese, a nossa renda triplicaria. (p .84)

Todavia, existiam resistências, no mercado brasileiro, à pressão exterior que se identificava com os produtos da revolução industrial. Nacionalistas defendiam a manufatura nacional (Bueno e Cervo, 2001, p. 138). Salvador de Mendonça, nos seus últimos artigos de jornal, insistiu em algumas teses nacionalistas, advogando em favor da industrialização do Brasil. Nesse ínterim, quanto a assuntos internos, a política doméstica apresentava sinais de fragilidade do Império, que era acusado de manter o país no atraso tecnológico e de torná-lo um corpo estranho à América republicana. Reclamava-se a americanização do Brasil e sua modernização como alternativa viável para o desenvolvimento econômico e político da nação. Fábio Murici dos Santos (2005, p. 1) comenta que, a partir da segunda metade do século XIX, a América passou a representar um símbolo de rejuvenescimento e de purificação para parcela significativa de homens públicos e intelectuais ibero-americanos. No caso brasileiro, precisamente, buscavam-se também referências para reformar o sistema monárquico, as quais miravam os Estados Unidos ou contemplavam uma utopia mais ampla de unidade continental. A América passava a ser, assim, uma nação que sugeria promessas para esse continente, conferindo-lhe um papel decisivo nas próximas etapas da história humana.

\section{Aristocracia brasileira, Império e República: cenários para a mudança de regime no Brasil.}

Salvador de Mendonça (1913, p. 3) era simpático à noção de América e República consoante à ideia de Fábio Murici dos Santos. Mendonça (1913, p. 1-2), que era defensor da inserção do Brasil no continente americano e militante republicano, afirmava que até a gente humilde, o povo analfabeto, escutava com adoração os oradores republicanos Lopes Trovão e Silva Jardim. A propaganda escrita, por seu turno, destinava-se aos homens educados. Dentre esses, estavam os monarquistas vira-casacas que traíram o Império e a incipiente República.

(...) A nossa Republica, puxada para o palco quando a enscenação não estava completa, e exposta ás vistas da platéa admirada, - Aristide Lobo disse-a bestificada, - tem sido até hoje um verdadeiro conto do vigario para os republicanos sinceros que a queriam melhor que o regimen decaído. Como os crentes eram apenas um punhado de homens, suppriram-lhes a

Revista Eletrônica da ANPHLAC, ISSN 1679-1061, n.15, p. 132-154, jul./dez. 2013. 
falta multidões de adhesistas, que para logo viram para onde se mudara a gamella do orçamento. Ora, como os monarchistas que vraram [sic] casaca não constituiam em sua maioria a flor do partido, e claro que os homens de mais elevada qualidade moral, quer liberaes quer conservadores, deixaram-se ficar aonde estavam e olharam com desdém para esta Republica sem republicanos. (MENDONÇA, 1913, p. 1-2)

Os monarquistas vira-casacas formavam uma aristocracia desprovida de valor, segundo Salvador de Mendonça (1913, p. 94-95). Para o autor, essa aristocracia se afastou do Império, porque não possuía tradições meritórias ou de serviços à pátria e, consequentemente, não se sentia responsável pelos destinos da Coroa brasileira. Ela fazia simplesmente proteger seus interesses, os quais, uma vez ofendidos como o foram com a abolição, a libertaram de qualquer compromisso com o imperador e o regime.

Salvador de Mendonça desferiu outros golpes de retórica contra a aristocracia brasileira. Mendonça lembrava que, na Europa, os aristocratas prestavam serviços às suas nações porque se sentiam comprometidos com elas. No Brasil, os aristocratas nunca se apresentaram para servir o país na guerra ou na paz. Na guerra, a aristocracia não conquistou terras ou dominou mares. Na paz, ela não prestou serviços relevantes nas artes ou nas ciências.

De acordo com Salvador de Mendonça (1913, p. 95), os aristocratas, que não tinham títulos nobiliárquicos, faziam dos nomes de família os seus brasões. A experiência aristocrática brasileira era, assim, epidérmica e superficial. Daí porque arredaram o trono quando perderam suas fortunas e se tornaram republicanos vira-casacas, posto não estarem afeitos ao hábito de firmar compromissos com ideias mais nobres e projetos nacionais.

Oliveira Lima (1937, p. 67) também refletia a esse respeito, mas por outro prisma, entendendo que as tensões vividas no Império eram provocadas por espíritos ambiciosos e por proprietários lesados pela abolição. Lima não comungava da má ideia sobre a aristocracia brasileira de Salvador de Mendonça, ele inclusive atribuía a essa aristocracia a formação de excelentes estadistas que teriam, cada qual em seu tempo, contribuído com a vida pública no Brasil. Os políticos que arredaram o trono eram pessoas com má disposição de caráter, as quais nunca serviram com honradez à própria República. Para Oliveira Lima (1937), os propagandistas republicanos se beneficiavam daquele cenário, porque encontravam um público ávido pelos seus discursos, bem como se favorecia a emergência de um novo tipo de homem público. Esses foram denominados por Lima (1937, p. 85) de políticos manhosos. Eles eram inescrupulosos e defendiam somente seus próprios interesses, de modo que não possuíam compromisso com o Império ou com a República. No Rio de Janeiro, capital do Império, os políticos manhosos aderiam aos republicanos e combatiam os monarquistas:

Revista Eletrônica da ANPHLAC, ISSN 1679-1061, n.15, p. 132-154, jul./dez. 2013. 
O facto da bomba republicana ter explodido quando se achava no poder uma situação liberal fez com que os conservadores adherissem mais depressa ao novo regimen e que os liberaes se sentissem obrigados a um curto retrahimento - a semana de nojo nas casas de finados [...]. (LIMA, 1937, p. 85)

Os republicanos foram igualmente analisados por Oliveira Lima (1937), através do Partido Republicano de Pernambuco. Esse partido era pouco numeroso, apesar da forte incorporação de senhores de engenho desgostosos com o Império. O partido também era recente e, por isso mesmo, não se relacionava com os apelos republicanos de 1817. O jovem Isidoro Martins Junior, discípulo de Tobias Barreto e influenciado pelas novas teorias do direito de caráter positivo, comandava a agremiação. Lima compreendia a República brasileira como uma construção incoerente e sem bases históricas, pois esses republicanos não possuíam tradição com movimentos anteriores que se manifestaram antes e durante a independência do Brasil. No caso dos políticos oriundos do Império, ele faz forte alusão ao oportunismo desses homens públicos, posto terem aderido ao novo regime como a única opção de preservar suas carreiras.

As representações de Oliveira Lima (1937) e de Salvador de Mendonça (1913) convergem no que tange aos discursos sobre os adesistas da República. Monarquistas vira-casacas ou políticos manhosos, eles não possuíam um projeto de nação, animando-se apenas contra perdas materiais causadas pela abolição. Como essa aconteceu no Império, a popularidade do regime diminuía sensivelmente. Mas nada impediria que eles se movessem contra a novel República, caso essa ferisse seus interesses, ou mesmo não os beneficiasse nas fileiras públicas.

O americanismo e a americanização da política externa do Brasil, por seu turno, pertenciam, enquanto discurso, aos republicanos históricos, como Salvador de Mendonça. No entanto, sua prática indica um conjunto de transformações de sentidos na confecção da República brasileira, os quais Mendonça condenara, ao afirmar que o regime brasileiro não se tornou, nem de longe, o sonhado pelos republicanos de boa-fé.

O Império limitou suas relações internacionais na América aos Estados Unidos, porque essas eram úteis, no sentido de conquistar vantagens comerciais e proteger o país de retaliações. Como afirmam Clodoaldo Bueno e Amado Cervo (2001, p. 140-141), construiu-se, assim, uma cordialidade pragmática e utilitária. Essa cordialidade não incluía, propriamente, o continente sulamericano, que não foi plenamente contemplado como o seria nos primórdios da República. Essa cordialidade fundava-se na ampliação do mercado norte-americano para o café brasileiro, na não ingerência do governo estadunidense frente às ações brasileiras sobre o Prata, na disposição daquele governo de apoiar diretamente a ocupação da Amazônia. Como contrapartida brasileira, tem-se a

Revista Eletrônica da ANPHLAC, ISSN 1679-1061, n.15, p. 132-154, jul./dez. 2013. 
abertura da economia nacional para inventos e investimentos sem, contudo, ceder tratado para restringir a soberania das decisões externas do Brasil.

O pragmatismo e o utilitarismo talvez representassem uma estratégia de enfrentamento político contra a Doutrina de Monroe, que perdia seu caráter hemisférico. A política externa estadunidense promovia expansão de fronteiras territoriais desde antes mesmo do governo de James Polk $^{10}$. Antecedeu a esse governo, a administração de John Tyler ${ }^{11}$. Com Tyler, que assumiu o comando do país, iniciou-se a questão do Texas.

O Texas pertencia ao México, como previsto na Constituição desse país, fazendo parte do estado de Coahuila. Essa região foi colonizada por grande número de imigrantes oriundos dos Estados Unidos, principalmente dos estados escravistas. Quando a Constituição do ano de 1824 foi revogada em 1833, os colonos do Texas se rebelaram e formaram o governo autônomo de 7 de novembro de 1835, que foi combatido pelo presidente mexicano Antonio Lopez de Santa-Anna ${ }^{12}$. As forças militares de Santa-Anna foram derrotadas no mês de abril de 1836 em San Jacinto. Nessa oportunidade, os texanos se declararam independentes e constituíram uma República. Ao longo de nove anos, a República texana permaneceu em paz, até que, em 1845, pedisse sua incorporação aos Estados Unidos.

Comandava o México nesse período o general Mariano Paredes y Arrillaga, que movimentou suas tropas no sentido de manter o Texas como território mexicano. As tropas de Mariano se bateram com forças estadunidenses, pois, nos Estados Unidos, a questão do Texas dividia opiniões. Existiam grupos de homens públicos que defendiam a autonomia da região, enquanto outros agrupamentos de políticos desejavam anexar a região aos Estados Unidos. O governo de John Tyler acompanhava amiúde a questão do Texas, mas de forma ainda tímida. As medidas mais incisivas, entretanto, foram promovidas pela administração do democrata James Knox Polk que impediu a reeleição de Tyler ao derrotá-lo nas urnas.

James Knox Polk defendia a expansão dos Estados Unidos e pertencia ao grupo que desejava a anexação, a qual de fato aconteceu em dezembro de 1845. Como o México não se conformou, os dois países pelejaram. As forças de Antonio Lopez de Santa-Anna, que retornara ao poder substituindo o general Mariano Paredes y Arrillaga, enfrentaram as tropas norte-americanas comandadas pelo general Zachary Taylor. As tropas estadunidenses já ocupavam o norte do México, e a derrota desse último país era inevitável. O fim do combate, com a derrota do México,

\footnotetext{
101845 a 1849.

111841 a 1845.

${ }^{12}$ Presidente por 11 vezes não consecutivas.
}

Revista Eletrônica da ANPHLAC, ISSN 1679-1061, n.15, p. 132-154, jul./dez. 2013. 
deu-se em 14 de setembro de 1847, e a paz foi concluída pelo tratado assinado em GuadalupeHidalgo em 2 de fevereiro de 1848.

Esse tratado de paz beneficiou deveras os Estados Unidos, que anexaram, além do Texas, vasta região, contribuindo, assim, para o projeto expansionista de alguns de seus homens públicos. Foram anexados os estados da Califórnia, de Nevada e Utah, além de parte do Colorado e a maior parte do Novo México e do Arizona. Reconheceu-se como fronteira meridional da Federação o Rio Grande.

A anexação beneficiou aos Estados Unidos, pois pouco depois James Marshall descobriria ouro na Califórnia. Com a descoberta de Marshall, a nação norte-americana conheceu um forte fluxo migratório, que se deu através das áreas anexadas. O povoamento dessas áreas foi, em certa medida, um golpe de sorte dado com a descoberta de ouro, mas ele impulsionou a conquista de zonas de fronteiras e a consequente expansão do país.

O fenômeno migratório representou um movimento interno e também de milhares de pessoas de outras partes do mundo. Os Estados Unidos tornavam-se, assim, uma espécie de país de diversas nações, com diversas matrizes culturais, e de pessoas que se sustentavam pelo sonho de um novo começo. Esse fenômeno, igualmente, modificou a política estadunidense, como revela a derrota de James Knox Polk para um destacado militar da guerra do Texas, Zachary Taylo, que faleceu em 1850, pouco depois de empossado.

A título de curiosidade, Millard Fillmore ${ }^{13}$ substituiu Zachary Taylor. Com Fillmore, a questão da escravidão retornou ao primeiro plano da agenda política norte-americana. Acredita-se que, com a anexação do Texas e de outros territórios conquistados na guerra contra o México, e também com a proposta do deputado David Wilmont de abolir o trabalho escravo nessa área, o ambiente de falsa cordialidade provocado pelo compromisso do Missouri se desfaria. Contudo, o importante para este nosso estudo são os novos sentidos adquiridos pela Doutrina de Monroe. Com essa guerra, seu foco se restringiu à esfera da América do Norte, para atender ao expansionismo territorial norte-americano em curso.

As alterações de sentidos do monroísmo foram observadas pelas demais nações da América do Sul. Elas compreendiam a Doutrina de Monroe, sobretudo após a anexação do Texas, como uma doutrina de interesse nacional estadunidense, que visava à expansão norte-americana. A política de James Polk reforçava um sentimento de desconfianças no continente americano contra os Estados Unidos, a ponto de se ter, inclusive, uma conversão momentânea do pan-americanismo para um

\footnotetext{
131850 a 1853.
}

Revista Eletrônica da ANPHLAC, ISSN 1679-1061, n.15, p. 132-154, jul./dez. 2013. 
pan-latinismo, o qual visava a promover a união americana com a exclusão dos Estados Unidos. Clodoaldo Bueno e Amado Cervo (2001, p. 141), que comentam essa conversão momentânea, inferem que o fracasso dessa iniciativa deu-se pela falta de adesão de todas as repúblicas sulamericanas.

O Brasil, por exemplo, distava das demais nações por sua composição social e forma de governo. Esse distanciamento dificultou sua participação nessa pretendida união, que excluía os Estados Unidos. Mas a chancelaria brasileira cuidou de justificar, com muito zelo, a sua ausência. O Império não desejava criar um foro hispânico de caráter antibrasileiro. O sentimento americanista, todavia, não encantava a diplomacia do Império, que simpatizava muito mais com o continente europeu, ainda assim, com uma Europa Ocidental. Essa diplomacia criticava os ideais bolivarianos, por supô-los extravagantes e por demais idealistas, o que incomodava o caráter pragmático dos diplomatas brasileiros. Além do que, os ideais bolivarianos eram vistos como uma representação estranha ao Brasil, pois, de alguma forma, eles manifestavam preocupações de segurança da América hispânica, que ainda se sentia ameaçada pelos espanhóis.

O Brasil não estava só nas críticas. Argentina e Estados Unidos também acusavam esses ideais de devaneios, percepções desprovidas de praticidade. O desprezo por doutrinas de arbitramento dos litígios internacionais era, contudo, algo próprio dos brasileiros. Compreensão que mudou junto com a alteração de regime no Brasil, pois os republicanos históricos, ao contrário dos monarquistas, percebiam a citada doutrina como benéfica para o país.

No caso particular dos Estados Unidos, nota-se certa despreocupação com os congressos americanos, apesar da tentativa frustrada de assistir aos trabalhos do Congresso do Panamá. Os dois delegados estadunidenses não compareceram, porque Richard C. Anderson faleceu durante a viagem, e o outro, John Sergeant, não saiu de Washington, ao saber que o evento havia sido interrompido e prosseguiria, posteriormente, em Tacubaya, no México (BUENO, 1997, p. 2). Os norte-americanos, porém, não admitiam qualquer tentativa de libertar Cuba do domínio espanhol, uma ideia acalentada pelos patriotas hispano-americanos, bem como não pensavam em abandonar sua neutralidade, opondo-se a qualquer tipo de aliança que julgassem comprometer seus interesses. Talvez, por essas posições, os norte-americanos realizariam o seu próprio Congresso no ano de 1889, que aconteceu quando a Doutrina do Destino Manifesto, pouco citada no discurso oficial desde a década de 1850, voltava à cena.

A Doutrina Monroe, ao fim e ao cabo, justificava o expansionismo estadunidense como direito de um povo eleito por Deus e senhor de experimentos políticos de caráter excepcional, que Cristina Soreanu Pecequilo (2005) identifica como um modelo republicano-democrático-liberal. Os

Revista Eletrônica da ANPHLAC, ISSN 1679-1061, n.15, p. 132-154, jul./dez. 2013. 
norte-americanos supunham esse modelo como criação sua e também original, porque distinto dos padrões europeus de organização civil. Modelo que, virtualmente, preservava a individualidade e premiava o mérito de sujeitos de bom coração, de muita energia e trabalhadores.

A Primeira Conferência Internacional Americana, também conhecida pela designação de Primeira Conferência Pan-Americana, realizada na capital dos Estados Unidos, contou com a participação de dezoito países da América. Para Clodoaldo Bueno (1997, p. 4), o encontro tinha a intenção de ampliar o intercâmbio comercial norte-americano com a América Latina, promovendo a prosperidade dos diversos Estados americanos por meio da união pan-americana de comércio. Esse encontro também se diferenciava do Congresso do Panamá, no sentido de privilegiar o comércio como elo integrador das nações.

O Brasil esteve presente para deliberar sobre a adaptação do sistema monetário, a conquista da paz continental, a criação de uma união aduaneira - mercado comum - do continente, a fundação de um banco continental, a modernização das comunicações e a unificação da legislação comercial. Para Clodoaldo Bueno e Amado Cervo (2001), entretanto, a Conferência pretendia construir um programa de dominação capitalista para a América:

\begin{abstract}
(...) As intenções do governo norte-americano visavam estabelecer, pela via do panamericanismo, uma reserva de domínio continental, a exemplo de como procediam os colonialistas europeus em suas áreas de expansão. Com isso, poderia manter o protecionismo diante das outras potências capitalistas e o liberalismo regional, em hábil manobra nacionalista. O congresso não era convocado por algum pretexto ocasional, como ocorrera anteriormente, mas em função de metas estruturais do desenvolvimento capitalista, de que se apropriavam os Estados Unidos para enquadrar em proveito próprio o continente como um todo. (p. 144)
\end{abstract}

Salvador de Mendonça era representante diplomático nos Estados Unidos e participava da Primeira Conferência Internacional Americana, quando soube da alteração de regime no Brasil. Ele informou que James Blaine comunicou pessoalmente a notícia de tal mudança aos brasileiros, por meio da apresentação de cópias dos telegramas enviados por Roberto Adams, ministro norteamericano no Rio de Janeiro. Dada a notícia, os acontecimentos se sucederam.

Salvador de Mendonça foi acusado de tramar contra o Império a partir dos Estados Unidos. Nesse sentido, Mendonça (1913) se defendia, afirmando que:

\footnotetext{
A verdade, porém, - e digo-a sem rebuço, - e que nutrindo a mesma crença republicana que sempre nutri, no primeiro momento estive para retirar-me a vida privada, por não acreditar na efficacia do processo empregado para a mudança do regimen político. Preferi-a feita no Parlamento, como a desejava o conselheiro Saraiva quando para isso estivesse o Brazil preparado e fosse esse o voto da maioria da nação (...). (p.113)
}

Revista Eletrônica da ANPHLAC, ISSN 1679-1061, n.15, p. 132-154, jul./dez. 2013. 
$\mathrm{E}$

Entretanto, posto de parte todo o interesse pessoal, acreditando sinceramente que a Republica viera para ficar e acceitando desde longo tempo o lemma de Franklin que "só dentro d'água se aprende a nadar", entendi não poder negar meu concurso as novas instituições, que durante toda a minha vida de imprensa procurara doutrinar com profunda sinceridade (...). (p.113)

Salvador de Mendonça (1913, p. 112) revelava profunda admiração e respeito a homens públicos do Império, como o fez ao congratular a inteligência do conselheiro Lafayette Rodrigues Pereira e de Saldanha da Gama. Para ele, as presenças de Gama e Pereira no Brasil talvez contribuíssem com outro desfecho nos acontecimentos que culminaram na derrocada do Império e na proclamação da República brasileira.

Salvador de Mendonça afirmava que o conselheiro Lafayette impediria o presidente do conselho de entrar no quartel-general e proporia, então, conduzir a família imperial para Minas Gerais. Saldanha da Gama comandaria o Riachuelo, obstando a defecção da esquadra. Mendonça refutou, contudo, qualquer estratégia sua para favorecer a República, apesar de professar fé inabalável nesse regime desde sua carreira na imprensa.

A República brasileira, entretanto, foi bem acolhida por parte das demais nações americanas. Argentina e Uruguai reconheceram o novo regime do Brasil, nas datas de 20 e 29 de novembro de 1889, respectivamente. O Chile o reconheceu posteriormente, em 13 de dezembro do mesmo ano (BUENO e CERVO, 2001, p. 151). Os Estados Unidos se manifestariam somente em 29 de janeiro de 1890.

Quintino Bocaiúva tornou-se ministro das Relações Exteriores do Governo Provisório e renovou os poderes da Missão Especial, cujos membros reagiram de formas distintas. O conselheiro Lafayette Rodrigues Pereira afastou-se, ao recusar a renovação. Amaral Valente telegrafou para o barão de Canindé, orientando-o a transferir suas economias para Londres. Iniciativa reprovada por Salvador de Mendonça (1913), pois “(...) a confiança que assim mostrava no governo novo do Brazil era quanto bastava para que o demitisse" (p.114).

As desconfianças com o futuro do novo regime brasileiro, contudo, não partiam somente de Amaral Valente. O presidente norte-americano Benjamin Harrison e o senador John Sherman, ambos republicanos, compreendiam ser coerente aguardar a manifestação da opinião pública brasileira. Temia-se um movimento que, com apoio popular, fizesse retornar ao Império ou, como sugere Salvador de Mendonça, que o imperador Pedro II houvesse conquistado os norteamericanos, apesar de seu espírito republicano. Situação complicada para a República do Brasil, como lembra Salvador de Mendonça (1913, p. 118), que, mesmo assim, administrou a situação, de

Revista Eletrônica da ANPHLAC, ISSN 1679-1061, n.15, p. 132-154, jul./dez. 2013. 
modo a beneficiar o novo regime do Brasil junto a James Blaine.

Clodoaldo Bueno e Amado Cervo (2001, p. 152) analisam a atitude dos Estados Unidos por meio de duas hipóteses: a boa impressão causada por Pedro II na sua visita a esse país no ano de 1876 e a ocorrência de indícios de que a República brasileira tendia a evoluir para uma ditadura militar. Das constatações de Bueno e Cervo (2001) sobre a atitude estadunidense, a ideia da boa impressão causada por Pedro II coincidia com as considerações de Salvador de Mendonça (1913).

Essas constatações dividiam as opiniões dos congressistas norte-americanos. Existiam, dentro dos dois partidos dos Estados Unidos, os que defendiam a cautela e os que defendiam o imediato reconhecimento da República brasileira. Dos parlamentares simpáticos à ideia do reconhecimento do novo regime do Brasil, destaca-se a figura do senador Morgan. Ele apresentou uma moção ao Senado, no mês de dezembro de 1889, recomendando o reconhecimento formal do regime em voga.

Os defensores da moção do senador Morgan argumentavam que o reconhecimento fortalecia os Estados Unidos. O governo estadunidense, ao impedir as nações europeias de colocar em perigo a República brasileira, mostraria ao mundo que o seu país não se intimidaria perante ameaças contra o continente americano. Afora o caráter romântico do discurso, pode-se contemplar um desejo bem prático por parte dos Estados Unidos. Defender o Brasil significava também incluir mais uma nação americana na esfera de influência estadunidense, no momento em que a América Latina era redescoberta pelos norte-americanos, os quais disputavam comercialmente a região, sobretudo, com os ingleses.

O reconhecimento norte-americano foi aprovado no Congresso por unanimidade. Decidiuse, igualmente, por uma moção congratulatória ao povo brasileiro pela adoção da República. Como afirmam Clodoaldo Bueno e Amado Cervo (2001, p. 153), a moção congratulatória insinuava interesses pelas mudanças institucionais no Brasil, aonde também afloravam desejos de aproximação com a potência hegemônica da América.

Não se pode negar, contudo, que o reconhecimento dos Estados Unidos contribuiu para a afirmação da República brasileira, que estava sob risco de não ser reconhecida por países da Europa. As nações europeias, a partir da decisão estadunidense, reconheciam, formal ou informalmente, o novo regime do Brasil. A Grã-Bretanha relacionava-se oficiosamente com o governo republicano, porque o Foreign Office compreendia a mudança institucional como fato consumado. A Inglaterra, porém, optou pela cautela até maio de 1891, quando reconheceu formalmente a República do Brasil (BUENO e CERVO, 2001, p. 154). A França retardou por algum tempo seu reconhecimento por dois motivos. Não se cogitava desagradar às monarquias

Revista Eletrônica da ANPHLAC, ISSN 1679-1061, n.15, p. 132-154, jul./dez. 2013. 
europeias e/ou encorajar republicanos espanhóis e portugueses. Por último, o decreto brasileiro de naturalização não era claro, e existia problema de limites com a Guiana. A França, entretanto, reconheceu o governo provisório em junho de 1890. Outras nações europeias reconheceram a República brasileira após a iniciativa dos Estados Unidos. Alemanha, Bélgica, Espanha, Itália e Portugal esperaram as eleições para proceder ao reconhecimento. A Rússia o fez em 26 de maio de 1892, após a morte de Pedro II.

O novo regime do Brasil vencia, portanto, uma primeira fase de turbulências, todas relativas à sua aceitação internacional. Dessa forma, os representantes diplomáticos desse país participavam dos trabalhos da Primeira Conferência Internacional Americana, os quais se encerraram em 1890. Salvador de Mendonça, especialmente, se dedicou ao assunto principal do encontro, o arbitramento obrigatório, de forma criativa e bastante entusiasmada.

Salvador de Mendonça (1913) pediu instruções ao governo brasileiro, manifestando o interesse de se alinhar às posições dos Estados Unidos e da maioria dos países americanos, porque

As instrucções que recebera do ultimo gabinete do Imperio a Missão Especial para os trabalhos da primeira Conferencia Internacional Americana, tendo aliás o cunho liberal que era de esperar da política que as dictara, no que dizia respeito ao assumpto principal da Conferencia - o arbitramento obrigatorio, estavam em desaccordo não só com o pensamento dos Estados Unidos da America, como também com o da quasi unanimidade das nações deste continente. Excepcao feita do Chile, cujos delegados deviamos acompanhar nessa questão, abstendonos de a discutir e votar, si tanto fosse preciso, todas as outras nações votariam unanimemente pela medida, cujas vantagens eram por todas reconhecidas. (p.138)

Salvador de Mendonça acreditava, assim, lograr posições mais republicanas para o Brasil na Primeira Conferência Internacional Americana. A resposta foi positiva, e Mendonça, convicto da consistência dessas posições, procurou os delegados argentinos Roque Saenz Peña e Manuel Quintana. Ele os convidou para redigir um projeto de arbitramento obrigatório, o qual foi aprovado, com algumas modificações, em 18 de abril de 1890.

\section{Reflexões sobre a participação brasileira na Primeira Conferência Internacional Americana e o Projeto de Arbitramento Obrigatório}

Nesta seção, observam-se as escolhas políticas da novel República brasileira, através das considerações de Salvador de Mendonça, entre elas, o Projeto de Arbitramento Obrigatório de James Blaine e Mendonça. Além disso, alude-se a uma política externa distinta da posterior, a qual seria desenvolvida por Rio Branco e Joaquim Nabuco em relação ao pan-americanismo.

Nesse sentido, o esforço da política externa defendida por Salvador de Mendonça, a mesma

Revista Eletrônica da ANPHLAC, ISSN 1679-1061, n.15, p. 132-154, jul./dez. 2013. 
política que possibilitou seu plano de arbitramento obrigatório, é criticado por pesquisadores contemporâneos. Clodoaldo Bueno e Amado Cervo (2001, p. 170) entendem essa política como uma ruptura inocente com a prática do Império, que defendia o Brasil no sentido de impedir seu ingresso no subsistema de poder patrocinado pelos Estados Unidos. O Império refutava o arbitramento, por temer que os estadunidenses se tornassem árbitros perpétuos na América. Já Bueno e Cervo (2001, p. 14-ss) acusam Mendonça de romper com a tradição de autonomia e cordialidade anteriores, por ser um caudatário dos interesses econômicos e políticos norteamericanos. Discorda-se aqui dessas interpretações.

De acordo com Salvador de Mendonça (1913, p. 165), a Primeira Conferência Internacional Americana foi esquecida, porque o presidente Harrison articulou, junto ao Congresso dos Estados Unidos, a reprovação do Projeto de Arbitramento Obrigatório.

Ainda segundo Salvador de Mendonça (1913), o presidente norte-americano temia que James Blaine se favorecesse politicamente com o projeto, porque estava

[...] receioso de que o secretario Blaine, entao apellidado de the Plumed Knight pelos seus partidários, se enfeitasse com a victoria do arbitramento obrigatório e da abolição da conquista entre as Nações Americanas na sua plataforma de candidato a successão presidencial [...]. (p.165)

A iniciativa de Harrison foi seguida por outras nações americanas, sacrificando o que Mendonça entendia como o resultado mais proveitoso dessa Conferência.

Salvador de Mendonça (1913, p. 167-168) ainda estava envolvido com as discussões sobre o arbitramento obrigatório, quando Quintino Bocaiúva manifestou a intenção de realizar um tratado de aliança com os Estados Unidos. Esse foi preterido por James Blaine, que preferia um tratado de comércio ou convenções aduaneiras, tendo por base favores recíprocos. Mendonça consultou o governo brasileiro, que atendeu à proposta de Blaine. $\mathrm{O}$ discurso oficial do governo brasileiro informava que, sendo os norte-americanos árbitros da questão das Missões, não era ético ter alianças com os juízes da contenda.

James Blaine e Salvador de Mendonça discutiram os resultados da Conferência Internacional Americana. Blaine e Mendonça consideravam a Conferência um meio sucesso, pois nela se estudaram as cláusulas para a convenção aduaneira e não se consolidou o tema principal: o arbitramento obrigatório. Brasileiro e estadunidense compreendiam que, para se lograr a eficiência do arbitramento, faltava elaborar sanções mais pormenorizadas, de modo a forçar as nações americanas a reconhecê-lo. Segundo Salvador de Mendonça (1913), James Blaine cogitava meios de completar o arbitramento em uma nova conferência pan-americana, a se realizar no Rio de

Revista Eletrônica da ANPHLAC, ISSN 1679-1061, n.15, p. 132-154, jul./dez. 2013. 
Janeiro. O brasileiro informava que ela não aconteceu, porque James Blaine foi preterido para a sucessão de Benjamin Harrison.

A derrota de James Blaine representou, igualmente, o sepultamento do plano BlaineMendonça. Ele pertencia ao programa de governo do norte-americano e previa a criação de tribunais internacionais de arbitramento, como também modificações substanciais na Doutrina Monroe. Supunham-se fundamentos de uma confederação, ou, ao menos, de uma dieta continental americana. Salvador de Mendonça (1913) exemplificava a ideia, utilizando como recurso a Primeira Conferência Internacional Americana, que representava aquelas dezoito nações do continente. Pelo plano Blaine-Mendonça, a participação das dezoito nações americanas se daria por meio de uma equação com índices no voto. Para cada nação, se asseguraria um voto por soberania. A esse voto, se somaria outro, oriundo de fração de cinco milhões de habitantes ou, pelo menos, de quinhentos mil. Cada país, entretanto, possuiria o voto por população, mesmo não alcançando meio milhão de habitantes.

A ideia surgira como complemento do arbitramento obrigatório, com o qual se pretendia eliminar de vez o direito à conquista e salvaguardar a soberania das nações americanas. $\mathrm{O}$ Tribunal Internacional Americano as protegeria. Por ter caráter permanente, o Tribunal se tornaria objeto principal do Congresso a se realizar no Rio de Janeiro. O Tribunal Internacional Americano seria composto por dois juízes nomeados por cada país. Eles teriam mandato de doze anos, mas um só votaria. Para substituí-lo, o seu governo obedeceria rigorosamente duas disposições: o impedimento ou a morte do juiz.

O Tribunal Permanente, de disposição trina, constituir-se-ia no local sorteado ao fim das reuniões e deliberaria questões internacionais americanas entre si ou com nações externas à América. Caso uma das partes não concordasse com a sentença, convocar-se-ia o tribunal pleno. Esse seria formado pela totalidade de juízes das nações americanas, teria a mesma sede e, à sua sentença, não caberia apelação.

Com vista a manter a autoridade do Tribunal Internacional Americano e obediência às sentenças, cada nação concorreria para a formação de forças regulares de mar e terra e de seus respectivos armamentos. A contribuição seria proporcional à população e receita de cada país, e as forças se constituiriam somente por ordem do tribunal pleno.

O comando das forças regulares respeitaria a precedência das patentes e, sendo essas iguais, seria dada prioridade à idade. Contudo, vale ressaltar que as nações disporiam de total autonomia para resolver seus negócios internos. Para Salvador de Mendonça (data), essa disposição substituiria a Doutrina Monroe, a qual ofendia a dignidade latino-americana, por favorecer o protetorado tácito

Revista Eletrônica da ANPHLAC, ISSN 1679-1061, n.15, p. 132-154, jul./dez. 2013. 
dos Estados Unidos. O plano Blaine-Mendonça, no fundo, guardava a concepção de América do brasileiro, a qual continuou no plano das boas ideias que são conduzidas ao esquecimento e ao silêncio imposto pelas interpretações dominantes.

Salvador de Mendonça também tratou de outros assuntos na Primeira Conferência Internacional Americana. O Convênio Aduaneiro de 31 de janeiro de 1891 prova a afirmação. O Governo Provisório o promulgou, por decreto, simultaneamente à proclamação do presidente dos Estados Unidos em 5 de fevereiro. O Convênio Aduaneiro e Salvador de Mendonça foram duramente criticados no Brasil. Tinha-se o Convênio como fator de empecilho à criação das indústrias manufatureiras. Clodoaldo Bueno e Amado Cervo (2001, p. 172) afirmam, inclusive, que se provocaram celeumas na opinião pública brasileira, porque muitos produtos vindos dos Estados Unidos possuíam tratamento tarifário preferencial no mercado brasileiro.

Salvador de Mendonça (1913, p. 187-188) contra-argumentava, ao afirmar que os discursos protecionistas se equilibravam sobre duas ilusões, pois não existiram até então esforços estatais de fundo para incrementar a industrialização no Brasil. A primeira ilusão, citada por ele, referia-se à farta emissão de papel-moeda para produzir capitalização e promover a criação de novas indústrias. A segunda se pautava na falsa concepção de que tarifas aduaneiras protegiam indústrias nacionais contra similares estrangeiras. Para as indústrias nacionais, faltavam elementos como facilidade de transporte, matéria-prima no próprio país e operários idôneos. Aliás, esse comentário de Salvador de Mendonça apresentava desafios que se desenhavam para a consolidação da República do Brasil no plano interno. A economia brasileira estava comprometida pela instabilidade institucional, em grande medida, resultante das disputas pelo comando do país. A instabilidade também comprometia a confiança internacional no regime.

Oliveira Lima (1937, p. 81) encontrava-se no Rio de Janeiro nesse período de incertezas na vida pública brasileira. Ele aguardava a ida para Portugal, acompanhando o cunhado Araújo Beltrão. O barão de Lucena os indicara e, assim, iniciava-se a carreira diplomática de Lima, que, durante a espera da viagem, acompanhava como analista privilegiado os distúrbios da política doméstica, dada sua proximidade do centro de poder. Nas suas lembranças, destacam-se os movimentos de opiniões e práticas nas ruas da capital.

O Rio de Janeiro era um turbilhão multifacetado nas representações de Oliveira Lima (1937), pois vários mundos se confundiam nessa cidade. Adesistas, monarquistas - sebastianistas e republicanos combatiam-se e mesclavam-se nos seus movimentos. Todos eles, porém, envolviamse apaixonadamente com os negócios da Bolsa, em uma experiência coletiva conhecida pelo nome de Encilhamento, política que significou uma tentativa de industrialização, com expansão do crédito

Revista Eletrônica da ANPHLAC, ISSN 1679-1061, n.15, p. 132-154, jul./dez. 2013. 
e desregulamentação da economia brasileira, como se pode observar:

O Rio, que eu conheci em 1890, com suas ruas estreitas em xadrez, que a diagonal da granvia ainda não cortava, com seus bonds de burros que vinham até a intersecção de Gonçalves Dias e Ouvidor, com o Lyrico e a febre amarella que, no dizer de um patriota, era o que nos salvava do domínio estrangeiro, dividia-se como a Roma de ha tempos passados, em um mundo branco e um mundo negro: d'um lado os republicanos e os adhesistas, muito mais numerosos estes; do outro lado os monarchistas, ja alcunhados de sebastianistas. Havia os temerarios, como Pedro de Barros, que se afoitavam a proclamar no meio da rua o seu tradicionalismo, mas no geral o elemento monarchico importava-se mais com os negocios da bolsa do que com a familia imperial (...). (p. 81)

Essa iniciativa - o Encilhamento - foi liderada por Rui Barbosa, em um cenário complexo que envolvia muitas variantes. O Brasil era produtor agrícola e abastecia centros do Atlântico norte. Sua produção dependia de boas colheitas e dos valores praticados no mercado internacional. O ciclo de investimento brasileiro, de plantio e de comercialização, vinculava-se ao crédito estrangeiro, aumentando a dependência do país perante o centro financeiro internacional. Deve-se observar ainda o insignificante desenvolvimento industrial que resultava da aplicação de capital acumulado com as exportações na compra de produtos manufaturados. Por outro lado, como lembra Jeffrey David Needell (1983, p. 31), o mercado interno brasileiro estava fortalecido. Aumentara o número de assalariados, dera-se o crescimento do risco comparativo de investimentos na agricultura, caíra o valor da moeda para a compra de produtos importados, e a mão de obra barata, vinda de áreas rurais da Itália e de Portugal, abundava.

Salvador de Mendonça (1913, p. 23-24) também observava o mercado interno brasileiro e, a respeito desse assunto, ele era muito crítico. Mendonça afirmava faltar capitalização para o desenvolvimento da economia do Brasil, a qual fazia o país viver da mão para a boca. O exemplo de o país viver da mão para a boca dava-se com as exportações não pagarem as importações, tampouco os serviços da dívida pública. Como consequência, o capital estrangeiro que entrava na nação era usado para o pagamento de grandes dividendos, e o Brasil não explorava suas potencialidades, como [ele] sugere:

Possuindo terras e climas proprios para quasi todos os productos necessarios á vida, chegávamos a importar de terras estrangeiras quasi todos os cereaes e fructos exoticos. Importavamos milho da Argentina, arroz da India e das Carolinas, fumo de Cuba e dos Estados Unidos, supplementando a nossa desidia com a compra risivel até de palha de milho para capas de cigarro. Tinhamos as mais extensas florestas do mundo e importavamos madeiras e mobilias estrangeiras. Neste particular o erro esta sendo corrigido pela Natureza: possuimos uns bichos proteccionistas que vao desacoroçando esta importação. Si ate importavamos palitos! (MENDONÇA, 1913, p. 23-24)

Os problemas internos do Brasil não passavam despercebidos aos observadores estrangeiros, os quais associavam a crise econômica à política. Quintino Bocaiúva publicava notícias nos mais

Revista Eletrônica da ANPHLAC, ISSN 1679-1061, n.15, p. 132-154, jul./dez. 2013. 
importantes jornais de Londres, para conter especulações que desvalorizavam títulos brasileiros. Cogitava-se, na bolsa britânica, que a instabilidade brasileira redundaria em prejuízo de ordem financeira aos investidores. Vale salientar que os ingleses investiam nos denominados países novos e, conforme Clodoaldo Bueno e Amado Cervo (2001, p 155-156), do conjunto dos recursos aplicados, parcela significativa era destinada ao Brasil. As suspeitas inglesas se fortaleciam quando, no Brasil, Deodoro da Fonseca se indispunha com as oposições e fechava o Congresso. Ou quando, de acordo com Oliveira Lima (1937), na abertura da Constituinte, monarquistas convertidos liam as pressas $O$ Federalista, para entender de direito constitucional americano, então matéria inédita no Brasil.

\begin{abstract}
[...] No seu seio havia jurisconsultos de valor como Jose Hygino, Amphilophio, João Barbalho, outros mais, familiares com Story e Kent, mas as discussões technicas tiveram sobretudo lugar na commissão dos 21 , que preparou o projecto de lei organica. O grosso dos congressistas, os luzeiros da democracia e os monarchistas convertidos e, como no geral acontece aos neophytos, ardendo em fé, tinha lido ás pressas o Federalista e realmente não podiam elles ter melhor texto para o seu curso de direito constitucional americano, em que o Brasil era leigo [...]. (LIMA, 1937, p. 92)
\end{abstract}

Os comentários críticos ao Brasil avançavam com muita rapidez. O cônsul inglês em Santos, F. H. Cowper, pedia paciência aos investidores do seu país. Cowper os aconselhava a esperar a consolidação da situação e definição do quadro político brasileiro. O ministro de Portugal no Rio de Janeiro, conde Paço d'Arcos, acreditava no ingresso do país em um período de crise financeira, com risco de desmembramento territorial.

O começo da República brasileira foi complicado, sobretudo pela consolidação e implantação de novas instituições. Passadas duas décadas, Salvador de Mendonça (1913) discutiu o tema na qualidade de veterano militante republicano, afirmando que o regime substituto da Monarquia não passava de um ensaio mal feito e incapaz de transmitir confiança, porque se arredava do povo. Dessa forma, se inviabilizava:

\footnotetext{
O futuro da nação brazileira esta pejado de incertezas. O ensaio mal feito ate hoje do regimen democratico presidencial que substituiu a Monarchia representativa, não tem inspirado em vinte e tres annos, quando já ultrapassa o periodo de mínoridade, a menor confiança em sua permanencia [...]. (p.1)
}

A maioria da população do Brasil era analfabeta e, por isso, não possuía consciência da mudança histórica que se operava no país. O analfabetismo do povo dificultou e, em grande medida, inviabilizou a missão dos republicanos históricos. A organização do Brasil ficou comprometida, porque o regime republicano e/ou democrático supunha a liberdade pautada na lei escrita. Essa era

Revista Eletrônica da ANPHLAC, ISSN 1679-1061, n.15, p. 132-154, jul./dez. 2013. 
inalcançável para a maioria da população, o povo.

Um povo que não sabe lêr e que portanto não póde conhecer as leis de sua terra é também claro que não pode obedecer a ellas, e na obediencia á lei esta o requisito principal de um bom regimen democratico. A obediencia a lei exclue á hypotese das revolucoes, que se tornam desnecessarias pelo livre exercicio do voto (...). (MENDONÇA, 1913, p. 4)

No povo, os republicanos repousaram o alicerce para a mudança de regime. $\mathrm{O}$ alicerce era frágil e nunca exerceu a liberdade, em especial, a do voto. Para Salvador de Mendonça (1913), "[...] o pico de pena dos mandões, fabricantes de atas falsas, escritas por ordem dos politiqueiros do centro aliados as oligarquias constituídas nos diferentes Estados" (p. 4) não o permitiu. A ausência popular na política favoreceu, de acordo com ele, a ascensão dos monarquistas vira-casacas. Eles alteraram a gamela do orçamento como também as políticas públicas. No fim, construíram uma República sem republicanos ou um ensaio malfeito, como Mendonça sugeriu anteriormente. Esses monarquistas originaram-se, principalmente, dos grupos de cafeicultores e de aliados que giravam em sua órbita.

Contudo, entre os monarquistas existiam pessoas que acreditavam nas promessas de futuro trazidas pela república. Salvador de Mendonça (1913) cita Afonso Pena, Antonio Prado, Rodrigues Alves e o conselheiro Saraiva como exemplos. Lembra-se que Afonso Pena e Rodrigues Alves foram presidentes da República, com o primeiro sucedendo o último. Por meio dessa leitura, Salvador de Mendonça discordava do discurso comum de que o vício de origem da República brasileira era o militarismo. Ele considerava um erro essa asserção porque, no Governo Provisório, as opiniões de civis predominavam. Aristides Lobo, Campos Sales, Demétrio Ribeiro e Quintino Bocaiúva não eram militares e exerciam influência nesse governo. Para Salvador de Mendonça, as falhas que comprometiam o regime se relacionavam, como visto, à falta de instrução popular.

\section{Conclusão}

A política externa do Brasil teve novas metas entre as décadas de 1870 e 1880. Procurou-se autoformulação de projetos e a condição de potência regional periférica, por meio de posturas como a distensão e o universalismo. A esse tempo, ocorreu aproximação com o Estados Unidos de forma cuidadosa, porque se temia um sistema interamericano no continente.

Aliás, em termos de continente, existiam concepções americanistas que, no Brasil, percebiam no Império a causa do atraso tecnológico da nação, como também um país desambientado por ser um império em meio a repúblicas.

Com a troca de regimes, tem-se um novo cenário político que, a despeito de ser republicano, Revista Eletrônica da ANPHLAC, ISSN 1679-1061, n.15, p. 132-154, jul./dez. 2013. 
não logrou o avanço tecnológico do país. Salvador de Mendonça (1913) e Oliveira Lima (1937) entendiam que a razão do insucesso da República se encontrava em um novo tipo de homem público, descompromissado com a pátria e interessado apenas em suas demandas pessoais. Mendonça percebia esse homem como originado da aristocracia que nunca teria servido o Brasil.

Em termos internacionais, os conteúdos e sentidos da Doutrina Monroe se associavam ao expansionismo estadunidense, os quais preocupavam os sul-americanos. Nesse sentido, na Primeira Conferência Internacional Americana, Salvador de Mendonça buscou a afirmação do Projeto de Arbitramento Obrigatório, para impedir a tutela tácita dos Estados Unidos sobre as demais nações americanas. Esse projeto não teve êxito, sendo reprovado, inicialmente, pelo Congresso norteamericano.

\section{Referências Bibliográficas}

BETHELL, Leslie. A Grã-Bretanha e a América Latina, 1830-1930. In: . História da América Latina. Brasília: Fundação Alexandre de Gusmão; São Paulo: Edusp: Imprensa Oficial do Estado, 2001. V. IV: de 1870 a 1930. p. 581-608.

BUENO, Clodoaldo. Da pax britannica à hegemonia norte-americana: o integracionismo nas conferências internacionais americanas (1826-1906). In: Estudos Históricos, Rio de Janeiro, n. 20, p. 231-250, 1997. Disponível em: <http://www.cpdoc.fgv.br/revista/arq/224.pdf.> Acesso em: 21/01/2008.

Editora Universidade de Brasília, 2001. (Coleção O Brasil e o Mundo)

FAUSTO, Boris; DEVOTO, Fernando J. Brasil e Argentina: um ensaio de história comparada (1850-2002). São Paulo: Editora 34, 2004.

LIMA, Oliveira. Memórias: estas minhas reminiscências... Rio de Janeiro: José Olympio, 1937.

MENDONÇA, Salvador de. Situação internacional do Brasil. Rio de Janeiro: Livraria Garnier, 1913.

NEEDELL, Jeffrey David. Belle Époque tropical: sociedade e cultura de elite no Rio de Janeiro na virada do século. São Paulo: Companhia das Letras, 1983.

PECEQUILO, Cristina Soreanu. Política externa dos Estados Unidos: continuidade ou mudança? $2^{\mathrm{a}}$ ed. Porto Alegre: Editora da UFRGS, 2005.

SANTOS, Fábio Murici dos. Um Éden germânico: Europa e América nas viagens de Oliveira Lima. In: Estudos Históricos, Rio de Janeiro, n. 35, p. 23-46, 2005. Disponível em: http://www.cpdoc.fgv.br/revista/arq/398.pdf. Acesso em: 07/01/2008.

Revista Eletrônica da ANPHLAC, ISSN 1679-1061, n.15, p. 132-154, jul./dez. 2013. 